\title{
National and landscape parks as a part of sustainable regional development in Northern Poland
}

\author{
Anetta Waśniewska ${ }^{1,}$, Hanna Kruk $^{1}$ \\ ${ }^{1}$ Gdynia Maritime University, Faculty of Entrepreneurship and Quality Science, Department \\ of Economics and Economic Policy, 81-87 Morska St., 81-225 Gdynia, Poland
}

\begin{abstract}
Sustainable development at a local and regional level depends on many factors. One of them, strictly related to biodiversity conservation and proper ecosystem functioning, is the presence of such protected areas as national (NP) and landscape (LP) parks in the region. Such forms of nature conservation are established in places of high environmental values. However, this also means restrictions and prohibitions that may limit possibility of local development. The main aim of the research is an attempt to study an influence of LP and NP on socio-economic development of communes in three provinces in the north of Poland (Western Pomerania, Pomerania, Warmia and Mazury). The results of examination survey sent to local authorities were used in the research. The results are ambiguous and may depend on the location of a particular park. Moreover, the majority of research respondents did not believe that the presence of such protected areas have a strong negative impact on communes, the local development and also pointed to some benefits related to NP and LP, like enhancing tourist attractiveness of the area.
\end{abstract}

\section{Introduction}

Regional development, according to Z. Strzelecki, means processes: economic (transformation of regional resources and factors into goods and services), technical and technological (improving effectiveness of economic processes), social ones (concerning the quality of life) and ecological development (exchange between human and nature) [1]. Development at a local and regional scale depends on many internal and external factors. Among them, one can mention the presence of large-area nature (wildlife and natural habitats) forms, including national parks (NP) and landscape parks (LP). It involves many bans and limitations that may influence the development potential of the region. At the area of the national park, where the whole nature is the subject of conservation, restrictions can be particularly burdensome. In the law of nature protection there is a list of 27 prohibitions to be enforced in each national park. In case of landscape parks the list of bans is shorter (17 items) and such restrictions can be, but do not have to be, obligatory within the area of a particular LP (it depends on specifics of the park and its nature protection plan) [2].

\footnotetext{
*Corresponding author: a.wasniewska@wpit.am.gdynia.pl
} 
It is commonly assumed that the presence of protected, areas marked with high nature values have a certain, negative impact on development potential of the communes located within the park's borders [3, 4]. Hitherto existing studies have provided inconclusive results. However, the prevailing opinion concerns the negative influence of such protected areas on local socio-economic development [5].

\section{Research aim, scope and results}

The aim of the research is to assess the impact of the national and landscape parks location, restrictions being, both, an effect of applicable law and the results of actions carried out by park service, on socio-economic development of communes situated within the NP or LP boundaries.

\subsection{Research method}

Three provinces in the Northern Poland were selected for the analysis: Western Pomerania, Pomerania and Warmia and Mazury. Within the areas of these provinces following parks are established:

1. Western Pomerania - 7 landscape parks: Iński LP, LP Puszcza Bukowa, LP Dolina Dolnej Odry, Cedyński LP, Drawski LP, LP Ujście Warty, Barliniecko-Gorzowski LP and 2 national parks: Drawieński NP and Woliński NP,

2. Pomerania -8 landscape parks: LP Mierzeja Wiślana, Wdzydzki LP, Trójmiejski LP, LP Dolina Słupii, Nadmorski LP, Tucholski LP, LP Pojezierza Iławskiego, Zaborski LP and also 2 national parks: NP Bory Tucholskie and Słowiński NP,

3. Warmia and Mazury - there are only landscape parks (8): LP Wysoczyzny Elbląskiej, LP Pojezierza Iławskiego, Brodnicki LP, Górznieńsko-Lidzbarski LP, Mazurski LP, LP Puszczy Rominckiej, Welski LP and LP Wzgórz Dylewskich.

Questionnaires (including open-ended and closed) questions were sent to 97 communes located within the NP and LP boundaries. Respondents to the survey were employees of the commune offices. 40 communes filled in and replied to the survey:

1. for the landscape parks there were: 7 municipalities, 22 rural communes and urbanrural communes,

2. for the national parks there were: 1 rural commune and 2 urban-rural ones (in case of one commune, some areas are located within LP and other in NP).

Less than $50 \%$ of the total area of the commune protected as the landscape park in case of the majority (40 communes) of the above-mentioned group. In case of 5 communes, more than $50 \%$ of their total area was within the LP and the whole area of 2 communes was included in the LP. In case of communes located in national park, for one more than $50 \%$ of the total area was in the NP, and for 2 other - less than $50 \%$.

\subsection{Empirical results}

Results of the survey may be divided into three problem areas, namely:

1. activities carried out by the park service and their importance for the commune,

2. burden of prohibitions and restrictions applied within the NP and LP,

3. commune staff's opinion about the impact of NP and LP on socio-economic development at local scale.

Staffs of both types of parks perform many tasks regarding ecological education, promotion of the region, active and passive nature conservation and also activities for local societies. The respondents were supposed to identify actions implemented by the park 
service and, using a 5-point scale, they assessed usefulness of such activities for the commune development (from the point: the task is not important to the answer: task is very important, crucial for the commune development). Not all actions were mentioned by the survey respondents, because various NP and LP performed different activities.

In the landscape parks, the most often implemented activities were:

1. education of inhabitants: in case of the children and the youth living in the region there were workshops, excursions, competitions, talks etc., in case of adults : thematic workshops for the employees of local and regional authorities, lectures for teachers and other groups,

2. multi-resource inventory (i.e. protected species, habitats, architectural monuments) and providing databases about natural and cultural values in the LP,

3. activities for tourists to the area: exhibitions, guiding groups etc.,

4. publication activities: publishing leaflets, guidebooks, maps, brochures promoting the region and also educational materials for teachers, students, description of educational pathways and others,

5. routing and arranging of ecological pathways, tourist trails (walking, cycling or horseback ones, waterways, Nordic walking and others),

6. data sharing the local and regional authorities (data needed to prepare local spatial arrangement planes, environmental impact assessment, reports etc.),

7. providing opinions on investment and other economic undertakings, planning permissions, etc.

The highest notes (important or very important task for the local development) were awarded to such activities like: children and youth education, inventory of the LP resources and providing the data to the local authorities, activities for tourists, routing and arranging tourist trails and ecological pathways (Fig. 1.).

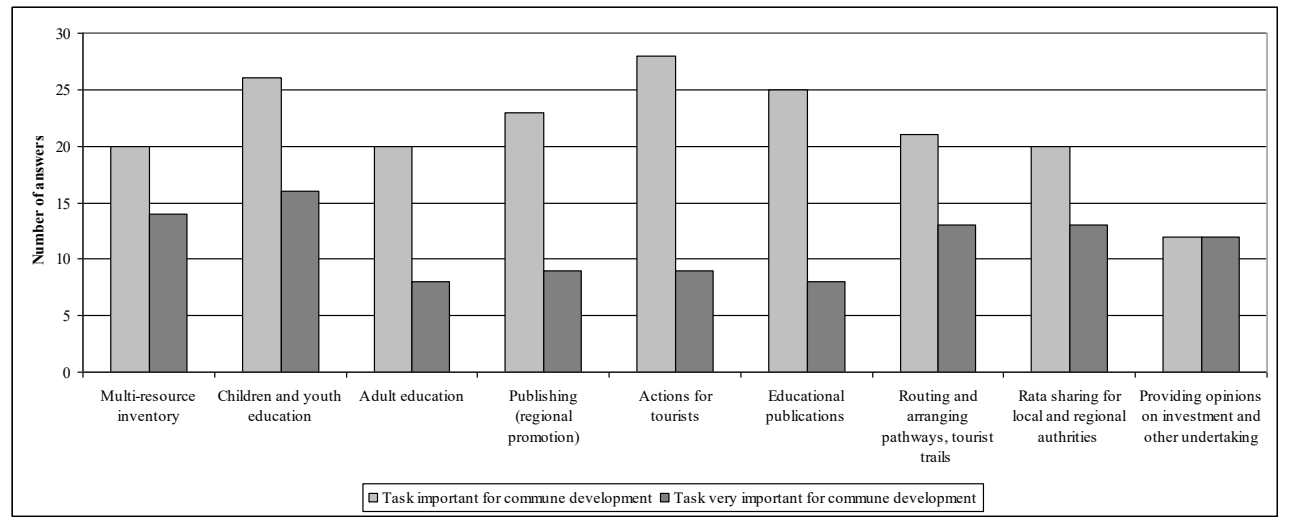

Fig. 1. Selected actions taken by LP staff found important for communes' development.

In case of the national parks, the commune representatives had very high opinion about educational activities (for various target groups), actions improving tourism attractiveness of the commune (including publishing) and preparing NP resource inventory and sharing its results with the authorities.

Survey respondents also replied to the question if they considered the park (LP and NP) staff activities were sufficient. In the majority of cases (table 1) the answer was affirmative.

Representatives of commune could also indicate other activities that should be performed by LP and NP service. The necessity to enhance education actions for adults (selected groups, including commune officials) increase their ecological awareness and the improvement of tourism attractiveness (publishing, tourist infrastructure, activities supporting agrotourism and nature tourism) were most often mentioned. People surveyed 
also often admitted that improvement of information flow between the parks and the commune office is needed. It is worth mentioning, that in case of a few parks, representatives of different local authorities (communes) pointed out various range of actions conducted by the same, particular park service. This may indicate a communication problem between the park and the commune.

Table 1. The number of answers to the question: If actions carried out by the park service are adequate?

\begin{tabular}{|c|c|c|}
\hline Statement & LP & NP \\
\hline $\begin{array}{c}\text { Actions are } \\
\text { sufficient }\end{array}$ & 29 & 3 \\
\hline $\begin{array}{c}\text { Actions are not } \\
\text { sufficient }\end{array}$ & 17 & 0 \\
\hline
\end{tabular}

Another question strictly related to the functioning of the national and landscape parks are restrictions and prohibitions on performing economic activity in protected areas. Not all survey respondents showed such limitations and bans, some of them even declared that constraint or ban is not burdensome for inhabitants. Commune representatives mentioned the following prohibitions as being the most severe: of:

1. logging and destroying bushes, hedges, wooded strips near roads, rivers, streams, field copses (21 answers),

2. locations of buildings or civil engineering works closer than 100 meters from water reservoirs or watercourses (19 answers) or closer than 200 meters form cliff and within the technical zone of the sea cost ( 1 answer),

3. implementation of initiatives that can have significant, negative environmental impact (14 answers) and certain limitations in construction (9 answers),

4. carrying out earthworks permanently changing topography of the area (9 answers) or water relations, including elimination of water reservoirs or wetlands (4 answers),

5. using motorboats and other motor equipment on open pool of water ( 7 answers),

6. litter-free (with absence of bedding) breed and raise of animals ( 7 answers),

It is noteworthy that in individual cases commune representatives confused restriction being the result of national or landscape park establishing with other restrictions or bans resulted from other legislation i.e. Natura 2000 areas (that often are situated in the areas of LP or NP) or prohibition of tree cutting during the bird breeding period [2].

Generally, representatives of commune offices, evaluating the influence of the national and landscape parks on socio-economic development at the local scale, most often believe that the parks partially limit such development (21 answers), have no impact on the commune development (14 answers) or have a positive influence (small: 12 answers or strong: 2 answers). In case of the national parks, where limitations are major, 2 answers pointed to the restrictive effect of the NP location, one - neutral (Fig. 2.). 


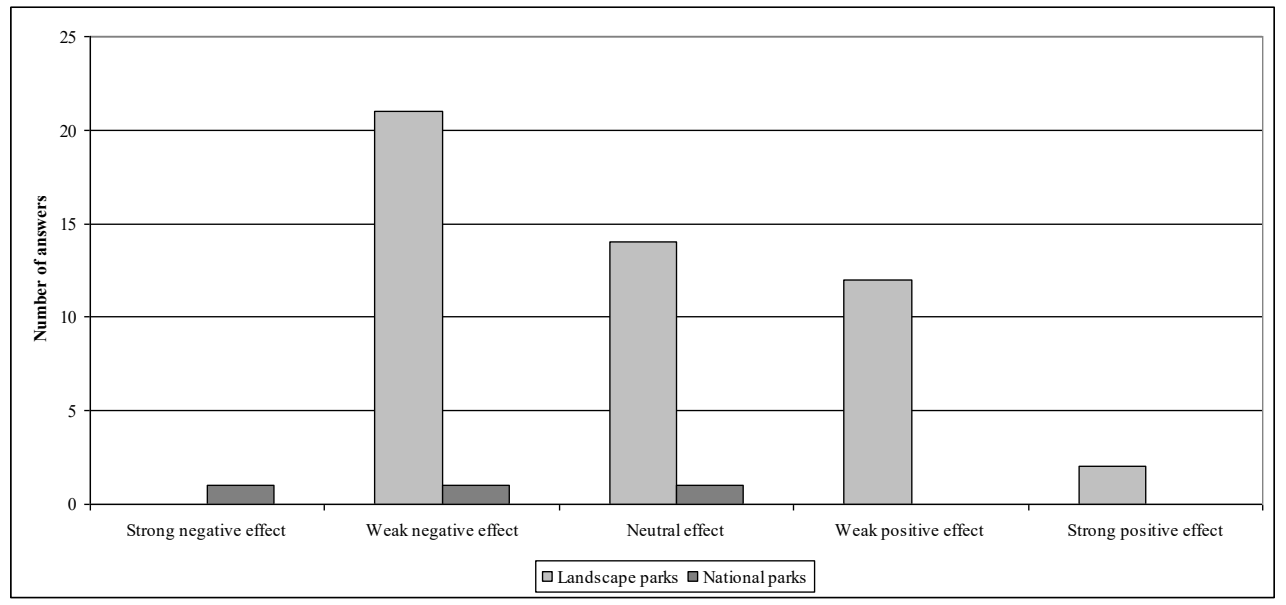

Fig. 2. Assessment of the NP and LP impact on socio-economic development of the communes.

Analyzes were also made of the dependencies resulting from the answers in the questionnaire to the question related to the tasks carried out by landscape and national parks altogether. The Pearson's linear correlation coefficient was used to investigate the interdependencies between respondents' responses [6].

Table 2. Activities undertaken by landscape and national parks.

\begin{tabular}{|c|c|c|c|}
\hline Variable & Activity & Variable & Activity \\
\hline $\mathrm{X} 1$ & $\begin{array}{c}\text { Natural inventory, historical objects } \\
\text { and creation of databases }\end{array}$ & $\mathrm{X} 7$ & $\begin{array}{c}\text { Activities aimed at tourists visiting the } \\
\text { region }\end{array}$ \\
\hline $\mathrm{X} 2$ & $\begin{array}{c}\text { Running a natural history museum, an } \\
\text { arboretum }\end{array}$ & $\mathrm{X} 8$ & $\begin{array}{c}\text { Training for the commune residents } \\
\text { regarding setting up producer groups, } \\
\text { promotion of regional products }\end{array}$ \\
\hline $\mathrm{X} 3$ & $\begin{array}{c}\text { Educational activities for children and } \\
\text { young people living in the region }\end{array}$ & $\mathrm{X} 9$ & $\begin{array}{c}\text { Training for commune residents } \\
\text { regarding agro-environmental } \\
\text { programs }\end{array}$ \\
\hline $\mathrm{X} 4$ & $\begin{array}{c}\text { Educational activities for adults } \\
\text { teachers, local government, residents) } \\
\text { in the field of agritourism, ecology, } \\
\text { etc. }\end{array}$ & $\mathrm{X} 10$ & $\begin{array}{c}\text { Designing and arranging paths, trails, } \\
\text { etc.. }\end{array}$ \\
\hline $\mathrm{X} 5$ & $\begin{array}{c}\text { Publishing activity in the field of } \\
\text { education and promotion of the region }\end{array}$ & $\mathrm{X} 11$ & $\begin{array}{c}\text { Providing data necessary to prepare a } \\
\text { spatial development plan }\end{array}$ \\
\hline $\mathrm{X} 6$ & $\begin{array}{c}\text { Employment of residents of the } \\
\text { commune while working in the park }\end{array}$ & $\mathrm{X} 12$ & $\begin{array}{c}\text { Assessment of investment locations, } \\
\text { building conditions, etc. }\end{array}$ \\
\hline
\end{tabular}

The first matrix contained values of correlation coefficients in relation to the answer "irrelevant from the point of view of the commune". The dependencies that are irrelevant due to the value of the correlation coefficient should be considered: educational activities for adults (workshops, lectures) or employment at works in the parks of the residents of the commune. Respondents also acknowledged that residents' trainings conducted by parks in the field of setting up producer groups, promotion of regional products and raising education of adult residents of municipalities, not conducive to the creation of spatial development plans or reports on environmental impacts. The sign at the value of the correlation coefficient indicates that these activities are opposite to each other. 


$$
\left[\begin{array}{rrrrrrrrrrrr}
1 & -0,5 & 0 & -0,5 & 0 & 0,5 & 0 & -1 & -0,5 & 0 & 0 & 1 \\
& 1 & 0 & 1 & 0 & 0,5 & 0 & 0,5 & -0,5 & 0 & 0 & -0,5 \\
& & 1 & 0 & 0 & 0 & 0 & 0 & 0 & 0 & 0 & 0 \\
& & & 1 & 0 & 0,5 & 0 & 0,5 & -0,5 & 0 & 0 & -0,5 \\
& & & & 1 & 0 & 0 & 0 & 0 & 0 & 0 & 0 \\
& & & & & 1 & 0 & -0,5 & -1 & 0 & 0 & 0,5 \\
& & & & & & 1 & 0 & 0 & 0 & 0 & 0 \\
& & & & & & & 1 & 0,5 & 0 & 0 & -1 \\
& & & & & & & & 1 & 0 & 0 & -0,5 \\
& & & & & & & & & 1 & 0 & 0 \\
& & & & & & & & & & 1 & 0 \\
& & & & & & & & & & & \\
& & & & & & & & & & & 1
\end{array}\right]
$$

Matrix 1. The matrix of correlation coefficients - tasks insignificant from the point of view of the commune.

Tasks that are not important in the development of a commune because of the value of the correlation coefficient are mainly: educational activities for adults, training in setting up producer groups or promotion of regional products and employment of municipal residents for works in the area of parks, publishing activity, as well as the sharing of data necessary for the preparation of spatial development plan. Among the obtained values of the correlation coefficient, a functional (full) relation was obtained between: giving opinions on the location of investments and other projects, and activities aimed at tourists visiting the region and adult education activities and their employment for work in parks.

$$
\left[\begin{array}{rrrrrrrrrrrr}
1 & 1 & 0 & -0,9 & 0,5 & -0,9 & 0,9 & 0,9 & -0,9 & 0,0 & 0,9 & 0,9 \\
& 1 & 0 & -0,9 & 0,5 & -0,9 & 0,9 & 0,9 & -0,9 & 0,0 & 0,9 & 0,9 \\
& & 1 & 0 & 0 & 0 & 0 & 0 & 0 & 0 & 0 & 0 \\
& & & 1 & -0,9 & 1 & -1 & -0,5 & 0,5 & -0,5 & -0,5 & -1 \\
& & & & 1 & -0,9 & 0,9 & 0,0 & 0,0 & 0,9 & 0,0 & 0,9 \\
& & & & & 1 & -1 & -0,5 & 0,5 & -0,5 & -0,5 & -1 \\
& & & & & & 1 & 0,5 & -0,5 & 0,5 & 0,5 & 1 \\
& & & & & & & 1 & -1 & -0,5 & 1 & 0,5 \\
& & & & & & & & 1 & 0,5 & -1 & -0,5 \\
& & & & & & & & & 1 & 1 & 1 \\
& & & & & & & & & & 1 & 0,5 \\
& & & & & & & & & & & 1
\end{array}\right]
$$

Matrix 2. The matrix of correlation coefficients - tasks of little importance from the point of view of the commune.

Moderately important tasks for the commune's development according to the respondents are: educational activities for children and young people living in the region, training for commune residents in the field of agro-environmental programs and training on setting up producer groups and sharing data on spatial development. 


$$
\left[\begin{array}{rrrrrrrrrrrr}
1 & 0,65 & -0,9 & 0,5 & 0,9 & 0,5 & 0,9 & -0,8 & 0,8 & 0,2 & 0,9 & 0,4 \\
& 1 & -0,9 & -0,3 & 0,9 & 1,0 & 0,9 & 0 & 0 & 0,87 & 0,9 & 1,0 \\
& & 1 & -0,2 & -1 & -0,8 & -1 & 0,5 & -0,5 & -0,5 & -1 & -0,7 \\
& & & 1 & 0,2 & -0,5 & 0,2 & -0,9 & 0,94 & -0,8 & 0,2 & -0,6 \\
& & & & 1 & 0,76 & 1 & -0,5 & 0,5 & 0,5 & 1 & 0,7 \\
& & & & & 1 & 0,8 & 0,2 & -0,2 & 0,9 & 0,8 & 1 \\
& & & & & 1 & -0,5 & 0,5 & 0,5 & 1 & 0,7 \\
& & & & & & 1 & -1 & 0,5 & -0,5 & 0,3 \\
& & & & & & & 1 & -0,5 & 0,5 & -0,3 \\
& & & & & & & & 1 & 0,5 & 1,0 \\
& & & & & & & & & 1 & 0,7 \\
& & & & & & & & & & 1
\end{array}\right]
$$

Matrix 3. The matrix of correlation coefficients - tasks moderately important from the point of view of the commune.

Activities that are important from the point of view of the commune and taken by landscape and national parks were considered all listed in Table 2 on the basis of calculations of the correlation coefficient except: educational activities for adults and employment of municipal residents for works for the benefit of parks and natural inventory, historical objects, which as a consequence, they allow to create databases of the nature of the region.

$$
\left[\begin{array}{rrrrrrrrrrrr}
1 & -0,5 & -0,2 & -1 & -0,5 & -0,9 & -0,5 & 0 & -0,8 & -0,3 & -1 & 0 \\
& 1 & -0,8 & 0,4 & -0,5 & 0,2 & -0,5 & 0,9 & 0,9 & -0,7 & 0,7 & 0 \\
& & 1 & 0,3 & 0,9 & 0,5 & 0,94 & -1 & -0,5 & 1 & -0,1 & 0 \\
& & & 1 & 0,6 & 1,0 & 0,6 & -0,1 & 0,7 & 0,4 & 0,9 & 0 \\
& & & & 1 & 0,8 & 1 & -0,9 & -0,2 & 1,0 & 0,3 & 0 \\
& & & & 1 & 0,8 & -0,3 & 0,5 & 0,6 & 0,8 & 0 \\
& & & & & 1 & -0,9 & -0,2 & 1,0 & 0,3 & 0 \\
& & & & & & 1 & 0,7 & -1 & 0,2 & 0 \\
& & & & & & & 1 & -0,4 & 0,9 & 0 \\
& & & & & & & & 1 & 0,0 & 0 \\
& & & & & & & & & 1 & 0 \\
& & & & & & & & & & 1
\end{array}\right]
$$

Matrix 4. The matrix of correlation coefficients - tasks important from the point of view of the commune.

On the other hand, all the key tasks undertaken by parks and influencing the socioeconomic development of the commune were considered except: running a natural museum, arboretum and reviewing the location of the investment. Based on the obtained values of the correlation coefficient it can be said that these two variables respondents found it organically for the development of the municipality. 


$\left[\begin{array}{rrrrrrrrrrrr}1 & -0,1 & 1,0 & 0,9 & 0,8 & -0,4 & 1 & 0,4 & 0,8 & 1 & 0,9 & -0,9 \\ & 1 & 0 & 0,2 & 0,5 & -0,9 & 0 & 0,9 & 0,5 & 0 & 0,3 & 0,5 \\ & & 1 & 1,0 & 0,9 & -0,5 & 1 & 0,5 & 0,9 & 1 & 0,9 & -0,9 \\ & & & 1 & 1 & -0,7 & 1 & 0,7 & 1 & 1 & 1 & -0,7 \\ & & & & 1 & -0,9 & 0,9 & 0,9 & 1 & 0,87 & 1 & -0,5 \\ & & & & & 1 & -0,5 & -1 & -0,9 & -0,5 & -0,8 & 0 \\ & & & & & & 1 & 0,5 & 0,9 & 1 & 0,9 & -0,9 \\ & & & & & & & 1 & 0,9 & 0,5 & 0,8 & 0 \\ & & & & & & & & 1 & 0,87 & 1,0 & -0,5 \\ & & & & & & & & & 1 & 0,9 & -0,9 \\ & & & & & & & & & & 1 & -0,7 \\ & & & & & & & & & & & 1\end{array}\right]$

Matrix 5. The matrix of correlation coefficients - tasks very important, even crucial from the point of view of the commune.

\section{Conclusions}

The results obtained are similar to the findings from other parts of the country [5, 7]. Many authors pointed to the high nature values of the national and landscape parks and therefore, high tourism potential of the communes located within the parks' borders $[4,8]$. One can assume that the lack of industry or serious restrictions in its localisation within the NP and LP may be compensated by the development of tourism. This fact was noted by the survey respondents, who also proposed further actions regarding that point. What is interesting, tourists usually valued more the natural values and benefits of the protected area than its inhabitants $[8,9]$.

Other research was focused on the entrepreneurs. Comparison of the entities (mainly micro-enterprises) located in rural areas (protected or not) showed insignificant differences in case of legal and operational structure, location factors or funding sources [10].

As for the findings of the above-mentioned survey, it may be assumed that the presence of such protected areas like national and landscape parks have negative influence on socioeconomic development of communes. This respondents' opinion about some negative impact of NP and LP prevail here. Mandatory restrictions and prohibitions can be burdensome for inhabitants. It should be emphasised that to most often mentioned limitations include these which allow to protect park's biodiversity and natural value of such areas.

On the other hand the park staff conduct many activities improving tourism attractiveness of the region and which are highly appreciated by the representatives of communes. Other actions are valued as well, i.e. education and inclusion of the residents and officials into nature protection activities. The survey respondents often postulated improvement of the information flows between NP or LP services, local authorities and inhabitants of the park. 


\section{References}

1. Z. Strzelecki, Polityka regionalna, In: Gospodarka regionalna i lokalna, (ed.) Z. Strzelecki (WN PWN, Warszawa, 2008)

2. Ustawa o ochronie przyrody, unified text after: isap.sejm.gov.pl (11.06.2018)

3. A. Bołtromiuk, Ekonomiczne aspekty funkcjonowania obszarów chronionych (Wyd. Uniwersytetu w Białymstoku, Białystok, 2003)

4. D. Pieńkowski, W. Zbaraszewski, Ekonomia i Środowisko 3, 284-294 (2016)

5. H. Kruk, A. Waśniewska, Prace Naukowe Uniwersytetu Ekonomicznego we Wrocławiu 450, 323-333 (2016)

6. A. D. Arczel, Statystyka w zarzadzaniu (Wydawnictwo Naukowe PWN, Warszawa, 2000)

7. H. Kruk, Prace Naukowe Uniwersytetu Ekonomicznego we Wrocławiu, 179, 71-80 (2011)

8. A. Kozak, D. Mączka, Economic and Regional Studies. Studia Ekonomiczne i Regionalne 9(3), 94-102 (2016)

9. K.A. Komorowska, Studia Regionalne i Lokalne 4, 133-151 (2000)

10. B. Grzebyk, Nierówności Społeczne a Wzrost Gospodarczy 48, 312-324 (2016) 